\title{
Restoration in soil and plant properties in landslide damaged forest ecosystem
}

\author{
Tej Narayan Mandal \\ Department of Botany, Post Graduate Campus, Tribhuvan University, Biratnagar, Nepal \\ E-mail: tnmandal@gmail.com
}

\begin{abstract}
The pattern of natural restoration in soil and plant components was studied in five landslide-damaged (1-58-year-old) sites in the tropical moist sal (Shorea robusta) forest ecosystem of Nepal Himalaya .Rate of restoration in soil properties was faster in the early successional stages (1-15 year) than late stages while plant biomass recovered rapidly after 15 -year age. Based on the recovery in ecosystem properties; the 58year-old landslide damaged site demonstrated the re-establishment of an ecosystem showing closer affinity with the mature sal forest. On the basis of best fit power function models it was concluded that the estimated times for the 58-year old site to reach the level of undisturbed matured sal forest would be about 30-35 years for microbial biomass (C and $\mathrm{N}$ ) and plant biomass and about 100-150 year for soil organic Carbon and total N. Higher accumulation of soil microbial biomass, plant biomass and high $\mathrm{N}$-mineralization rate at late successional stages indicated the re-establishment of an ecosystem with enriched soil and restitution of nutrient cycling during the course of ecosystem restoration
\end{abstract}

Key words: Disturbance, restoration, soil biomass, biodiversity, plant biomass

\section{Introduction}

Restoration of degraded lands has been accepted as a challenge to demonstrate the scope of ecology in resource management and sustainable development as it requires a thorough understanding of the ecological principles. In fact, ecological restoration is a practical test of our ecological understanding. Bradshaw (1987) called restoration as an "acid-test for ecology". Ecology plays a central role in the implementation of restoration projects. Restoration ecologists have emphasized concepts such as ecosystem health and ecosystem integrity when articulating restoration goals. Obviously their objectives are based on ecological principles (SER, 2002). Natural as well as man-induced disturbances disrupt the normal functioning of different ecosystems. Consequently, the sustainability of ecosystem functioning becomes dependent on the scale and intensity of the disturbances. Hence, restoration of degraded ecosystem is of paramount importance to regain and re-establish these functions.

Disturbance is a discrete event in time that disrupts ecosystem community, or population structure and changes resources availability (Pickett \& White, 1985). Ecosystem disturbance alters the relationships of organisms and their habitats from their natural state. The ecosystem subjected to catastrophic disturbances is unlikely to be in equilibrium rather it is expected to be in a dynamic state of recovery from the past disturbances. Thus the 
disturbance acts as an important force which contributes to the dynamics of structure and function of ecosystems (Bormann \& Likens, 1979). Generally the destruction of habitat results in loss of biodiversity, degradation in ecosystem structure and changes in the ecosystem functions. Disturbed ecosystems show changes in species composition, density, stand biomass, productivity and in the patterns of nutrient cycling.

Recovery pattern in different components of landslide damaged forest ecosystem has been documented by Garwood (1985), Guariguata (1990) and Singh et al. (2001). In the present study, the pattern of natural restoration in soil and plant components has been documented in five landslide-damaged (1-58-year-old) sites in the tropical moist Sal (Shorea robusta) forest ecosystem of Nepal Himalaya. Comparisons were made with an undisturbed forest site in the same region.

\section{Materials and Methods}

\section{Study area}

The study was conducted in Eastern Siwaliks (Sub-Himalayan region), the catchment area of Koshi River (one of the largest rivers in Nepal), adjacent to Dharan, Nepal $\left(26^{\circ} 47^{\prime}\right.$ $26^{\circ} 52^{\prime} \mathrm{N} \& 87^{\circ} 14^{\prime}-87^{\circ} 22^{\prime} \mathrm{E}$ ), within the altitude range of 450 to $750 \mathrm{msl}$. An age series of 1 , $4,15,40,58$-year-old landslide damaged sites in a sal forest ecosystem and a mature $(>100$ years old) undisturbed sal forest, treated as a reference forest, were selected for this study.

\section{Chemical analysis}

Soil samples were collected from three random locations at each site. At each location the soil was collected from three pits, composited and pooled as one replicate. Soil sampling was carried out in May, July and January (1993-1995), representing the summer, rainy and winter season, respectively. Organic $\mathrm{C}$ was analysed by dichromate oxidation in a reflux system and titration with ferrous ammonium sulphate (Kalembasa \& Jenkinson, 1973). Total $\mathrm{N}$ was estimated by micro-Kjeldahl method (Jackson, 1958). Soil microbial biomass $\mathrm{C}$ and $\mathrm{N}$ were estimated by chloroform fumigation extraction method (Vance et al., 1987b). $\mathrm{NO}_{3^{-}}$ $\mathrm{N}$ was meausred by phenol disulphonic acid method, using $\mathrm{CaSO}_{4}$ as the soil extractant (Jackson, 1958). $\mathrm{NH}_{4}-\mathrm{N}$ was estimated by phenate method (Wetzel \& Likens, 1979), using 2 $\mathrm{M} \mathrm{KCl}$ as the soil extractant.

\section{Nitrogen mineralization}

$\mathrm{N}$-mineralization was measured in situ by buried bag technique (Eno, 1960). $\mathrm{NO}_{3}-\mathrm{N}$ and $\mathrm{NH}_{4}-\mathrm{N}$ were determined initially (at time zero) and the recovery of buried bags after one month. The increase in the concentration of ammonium- $\mathrm{N}$ plus nitrate- $\mathrm{N}$ during the field incubation was estimated as the net $\mathrm{N}$-mineralization (Pastor et al., 1984). The increase in $\mathrm{NH}_{4}-\mathrm{N}$ was considered as ammonification and the increase in $\mathrm{NO}_{3}-\mathrm{N}$ as the nitrification.

\section{Vegetation analysis}

For vegetation analysis 10 permanent tree plots (each $10 \times 10 \mathrm{~m}^{2}$ ) and 10 nested shrub plots (each $5 \times 5 \mathrm{~m}^{2}$ ) were randomly established in sites of 15 -year or greater in age. Species diversity parameters such as Species richness (Margalef, 1958), Shannon-Wiener index (Shannon \& Weaver, 1963), Equitability (Evenness) (Pielou, 1966), Index of dominance (Simpson, 1949) were determined from density values. 


\section{Estimation of plant biomass production}

Biomass of trees in plots was estimated by using girth:biomass allometric equations for submontane sal forest in southern Siwaliks (available only for trees $\geq 30 \mathrm{~cm}$ girth) published by Singh and Singh (1992). Using the allometric equations, the biomass of different components of marked trees/shrubs in permanent plots was computed for $1994\left(\mathrm{~B}_{1}\right)$ and $1995\left(B_{2}\right)$ from respective girth measurements for estimation of production. Fine roots $(<10$ $\mathrm{mm}$ diameter) biomass was determined from five soil monoliths $\left(10 \times 10 \times 30 \mathrm{~cm}^{3}\right.$ depth $)$ on each site.

\section{Litter mass and litterfall}

Litter mass accumulated at each site was collected once every season from five $1 \times 1 \mathrm{~m}^{2}$ randomly placed plots and separated as: (a) fresh leaf litter, (b) partly decayed litter and (c) non-leaf litter (including reproductive parts). For the estimation of litter fall five litter traps $\left(1 \times 1 \mathrm{~m}^{2}\right)$ was randomly fixed on the forest floor at each site. The turnover rate $(k)$ of litter was calculated following Jenny et al. (1949).

\section{Results and Discussion}

Concentrations of soil organic $\mathrm{C}$ and total $\mathrm{N}$ increased with the age of sites. The 58-year-old site showed concentrations of soil organic $\mathrm{C}$ and total $\mathrm{N}$ that were $75-89 \%$ of concentrations in the undisturbed Sal forest (Tab. 1). The soil microbial biomass, the active fraction of soil organic matter (expressed as $\mathrm{C}$ and $\mathrm{N}$ contents) increased 4-5 times at the 58-year-old site relative to the 1-year-old site, and the bulk increase occurred within the initial 15 year. Although the net $\mathrm{N}$-mineralization rate increased consistently until 58 years of age, the proportion of nitrification rate relative to ammonification rate distinctly decreased beyond 40 years. On the other hand, the soil available-N (both $\mathrm{NO}_{3}{ }^{-}$and $\mathrm{NH}_{4}{ }^{+}$) concentrations increased from 1-40 year and then declined; with age the proportion of $\mathrm{NH}_{4}{ }^{+}$increased, however. Rates of restoration in soil properties were faster in the early successional stages (1-15 year) than late stages. Among different soil properties the restoration of soil microbial biomass ( $\mathrm{C}$ and $\mathrm{N}$ ) was faster than soil organic $\mathrm{C}$ and total $\mathrm{N}$ (Singh et al., 2001).

Table 1. Comparative account of soil properties (0-10 $\mathrm{cm}$ depth) in landslide sites and mature sal forest (MF) in Nepal Himalaya.

\begin{tabular}{lllllll}
\hline Parameters & \multicolumn{5}{c}{ Age of site (years) } \\
\cline { 2 - 7 } & $\mathbf{1}$ & $\mathbf{4}$ & $\mathbf{1 5}$ & $\mathbf{4 0}$ & $\mathbf{5 8}$ & $\mathrm{MF}$ \\
\hline Organic C $\left(\mathrm{t} \mathrm{ha}^{-1}\right)$ & 13.0 & 15.0 & 21.0 & 25.0 & 28.0 & 33.0 \\
Total $\mathrm{N}\left(\mathrm{t} \mathrm{ha}^{-1}\right)$ & 1.36 & 1.44 & 2.01 & 2.37 & 2.64 & 3.20 \\
Microbial biomass $\mathrm{C}\left(\mu \mathrm{g} \mathrm{g}^{-1}\right)$ & $132.0 \pm 13$ & $215.0 \pm 18$ & $408.0 \pm 30$ & $568.0 \pm 43$ & $638.0 \pm 43$ & $778.0 \pm 51$ \\
Microbial biomass $\mathrm{N}\left(\mu \mathrm{g} \mathrm{g}^{-1}\right)$ & $14.0 \pm 1.7$ & $21.0 \pm 2.3$ & $38.0 \pm 3.3$ & $50.0 \pm 4.6$ & $55.0 \pm 3.9$ & $65.0 \pm 5.4$ \\
Ammonification $\left(\mu \mathrm{g} \mathrm{g}^{-1} \mathrm{mo}^{-1}\right)$ & $1.33 \pm 03$ & $2.00 \pm 0.4$ & $3.90 \pm 0.7$ & $5.66 \pm 1.0$ & $9.53 \pm 1.7$ & $11.76 \pm 2.0$ \\
Nitrification $\left(\mu \mathrm{g} \mathrm{g} \mathrm{mo}^{-1}\right)$ & $2.50 \pm 06$ & $4.16 \pm 1.0$ & $6.83 \pm 1.6$ & $8.00 \pm 1.8$ & $6.00 \pm 1.3$ & $5.56 \pm 1.1$ \\
$\mathrm{~N}-$ mineralization $\left(\mu \mathrm{g} \mathrm{g}^{-1} \mathrm{mo}^{-1}\right)$ & $3.83 \pm 0.8$ & $6.16 \pm 1.4$ & $10.73 \pm 2.3$ & $13.66 \pm 2.8$ & $15.53 \pm 3.0$ & $17.32 \pm 3.5$ \\
Ammonification: $\mathrm{Nitrification}^{-1}$ & 0.53 & 0.48 & 0.57 & 0.70 & 1.58 & 2.11 \\
Available-N $\left(\mu \mathrm{g} \mathrm{g}{ }^{-1}\right)$ & $2.8 \pm 0.5$ & $4.0 \pm 0.6$ & $14.2 \pm 2.0$ & $16.4 \pm 2.0$ & $13.5 \pm 1.6$ & $12.4 \pm 1.7$ \\
$\mathrm{NH}_{4}-\mathrm{N}: \mathrm{NO}_{3}-\mathrm{N}$ & 1.15 & 1.35 & 1.50 & 1.73 & 2.20 & 2.40 \\
\hline
\end{tabular}

Disturbance due to landslide resulted in a reduction in species diversity. In the herbaceous species Shannon-Wiener index reduced to 1.71 in 1-year-old site in comparison to 2.57 in mature Sal forest. Similarly, species richness was minimum (3.4) at 1-year-old site (Tab. 2). 
However, these parameters exhibited an increasing trend with the passage of time and reached to maximum level at the 40-year-old site (3 \& 9 respectively), when the concentration dominance was conversely minimum (0.06). Among the trees, diversity parameters revealed that the Shannon-Wiener index and the species richness increased while concentration of dominance decreased with the age of successional communities (Tab. 2). The 50-year-old site exhibited highest value (1.72) for tree diversity which was slightly higher than that of the mature Sal forest. Maximum level of herb biodiversity at 40-year old site was assumed to be due to the mixture of early successional species (shade intolerant), intermediate successional species and late successional species (shade tolerant). Based on "Intermediate Disturbance Hypothesis" (Grime, 1979; Huston, 1979), van der Marrel (1993) concluded that under moderate level of disturbance, biodiversity is highest in intermediate successional stage.

Table 2. Comparative account of plant properties in landslide sites and mature sal forest (MF) in Nepal Himalaya.

\begin{tabular}{|c|c|c|c|c|c|c|}
\hline \multirow{2}{*}{ Parameters } & \multicolumn{5}{|c|}{ Age of site (years) } & \multirow{2}{*}{-MF } \\
\hline & 1 & 4 & 15 & 40 & 58 & \\
\hline \multicolumn{7}{|l|}{ Species richness $(d)$} \\
\hline Trees & & & 1.1 & 1.71 & 1.82 & 1.57 \\
\hline Shrubs & & & 0.79 & 1.1 & 1.1 & 1.2 \\
\hline Herbs & 3.4 & 4.8 & 8.7 & 9.0 & 8.34 & 6.34 \\
\hline \multicolumn{7}{|l|}{ Shanon-Wiener index $\left(H^{\prime}\right)$} \\
\hline Trees & & & 1.12 & 1.59 & 1.72 & 1.66 \\
\hline Shrubs & & & 1.70 & 2.00 & 2.00 & 2.00 \\
\hline Herbs & 1.71 & 2.10 & 2.88 & 3.00 & 2.81 & 2.57 \\
\hline \multicolumn{7}{|l|}{ Index of dominance $(c)$} \\
\hline Trees & & & 0.52 & 0.35 & 0.30 & 0.30 \\
\hline Shrubs & & & 0.21 & 0.15 & 0.16 & 0.17 \\
\hline Herbs & 0.27 & 0.19 & 0.08 & 0.06 & 0.08 & 0.11 \\
\hline$\overline{\text { Biomass }\left(\mathrm{t} \mathrm{ha}^{-1}\right)}$ & $0.8 \pm 0.1$ & $3.8 \pm 0.2$ & $101.0 \pm 19$ & $476.0 \pm 33$ & $547.0 \pm 63$ & $729.0 \pm 82$ \\
\hline Herbs* & $0.5 \pm 0.1$ & $2.2 \pm 0.2$ & $1.8 \pm 0.1$ & $1.5 \pm 0.1$ & $1.5 \pm 0.1$ & $1.1 \pm 0.1$ \\
\hline Shrubs & - & $0.4 \pm 0.1$ & $1.0 \pm 0.1$ & $3.3 \pm 0.5$ & $4.1 \pm 0.3$ & $4.4 \pm 0.3$ \\
\hline Trees & - & - & $94.0 \pm 118$ & $465.0 \pm 33$ & $534.0 \pm 63$ & $715.0 \pm 83$ \\
\hline Stand fine root & $0.3 \pm 0.02$ & $1.2 \pm 0.06$ & $4.4 \pm 0.27$ & $5.8 \pm 0.31$ & $7.0 \pm 0.34$ & $8.2 \pm 0.49$ \\
\hline Net production $\left(\mathrm{t} \mathrm{ha}^{-1} \mathrm{yr}^{-1}\right)$ & 0.9 & 3.5 & 19.5 & 26.7 & 23.6 & 22.1 \\
\hline Herbs* & 0.6 & 2.0 & 1.7 & 1.4 & 1.2 & 1.0 \\
\hline Shrubs & - & 0.3 & 0.8 & 1.9 & 1.0 & 1.3 \\
\hline Trees & - & - & 12.7 & 18.1 & 15.1 & 13.4 \\
\hline Stand fine root & 0.3 & 1.2 & 4.3 & 5.3 & 5.9 & 6.4 \\
\hline $\mathrm{BAR}^{* *}$ & 0.9 & 1.1 & 5.2 & 17.8 & 23.2 & 33.0 \\
\hline Litterfall $\left(\mathrm{t} \mathrm{ha}^{-1} \mathrm{yr}^{-1}\right)$ & $0.3 \pm 0.03$ & $0.9 \pm 0.05$ & $5.6 \pm 0.62$ & $8.8 \pm 0.83$ & $9.7 \pm 0.80$ & $10.3 \pm 0.61$ \\
\hline Litter mass $\left(\mathrm{t} \mathrm{ha}^{-1}\right)$ & $0.14 \pm 0.08$ & $0.4 \pm 0.04$ & $2.9 \pm 0.2$ & $4.5 \pm 0.034$ & $5.1 \pm 0.3$ & $5.6 \pm 0.5$ \\
\hline Turnover; fine root & 1.0 & 1.0 & 0.97 & 0.91 & 0.84 & 0.78 \\
\hline Turnover; litter & 0.90 & 0.87 & 0.81 & 0.78 & 0.77 & 0.78 \\
\hline
\end{tabular}

*Aboveground parts, **BAR (Biomass Accumulation Ratio)

Stand plant biomass and production, fine root biomass and production and organic matter input through litter and fine roots were faster in the younger sites ( 1 to 40 year-old) and bulk increase occurred after 15 year. As the patterns of recovery were slower at 58-year-old site, the forests of this site may require considerable time to reach the level of mature Sal forest. 
BAR (Biomass Accumulation Ratio) showed an increasing trend with the age of the sites which indicated a low biomass and high net production state at the early successional stages (greater production efficiency) and high biomass and low production rate (low production efficiency) at the late successional stages.

Landslide disturbed ecosystem showed several ecosystem level strategies which geared the damaged system to recover rapidly with passage of time. Fast growing nutrient rich herbs at younger sites play an important role in rapid accumulation of soil organic matter by their highly decomposable soft tissue. Increasing level of litter and fine roots in the developing vegetation and their high turnover rates to release nutrients rapidly in the younger sites probably contribute significantly to continual regeneration of available $\mathrm{N}$ in soil to support a high net production of developing ecosystem.

Soil microbial biomass which increased with the age of landslide sites reflected the activities in rapid decomposition, and mineralization in younger sites which become the constant source of available nutrients. High rate of decomposition, mineralization and high nutrient uptake in the early stages, exhibit the capacity for rapid remobilization of resources reflected by high rate of net production in developing vegetation. Such strategies may efficiently contribute to the resilience of the damaged ecosystem to recover rapidly.

With passage of time, the maturity of the sites was reflected in strong nutrient conserving mechanisms. Significant retranslocation of nutrients from senescing leaves and immobilization of nutrients in litter mass in the older sites are the important nutrient conservation strategies to retain the nutrients within the system and to release them later for plant use. High nutrient use-efficiencies in the older sites showed relationship with high retranslocation efficiency (Mandal, 1999). The sustainability of ecosystem functioning in response to environmental perturbations depends upon the capacity of the plant and soil subsystems to buffer or accommodate losses of key nutrients following disturbance.

In the present study, the 58-year-old site demonstrated the re-establishment of soil nutrients, plant biomass, microbial biomass and nutrient cycling and as a whole a sustainable ecosystem after the landslide disturbance. The recovery in ecosystem properties exhibits a positive feedback relationship and moves the disturbed ecosystem rapidly towards a stable nutrient status and its cycling. Based on the recovery in ecosystem properties, the 58-yearold landslide damaged site demonstrated the re-establishment of an ecosystem showing closer affinity with the mature Sal forest.

On the basis of best fit power function models it was concluded that the estimated times for the 58-year-old site to reach the level of the undisturbed, mature Sal forest would be about 30-35 year for microbial biomass (C \& N) and plant biomass and about 100-150 year for organic $\mathrm{C}$ and total $\mathrm{N}$. Higher accumulation of soil microbial biomass, plant biomass and high $\mathrm{N}$-mineralization rate at late successional stages indicated the re-establishment of an ecosystem with enriched soil and restitution of nutrient cycling during the course of ecosystem restoration

\section{Acknowledgements}

The author is grateful to Prof. K.P. Singh for guidance and to the Head, Department of Botany, Banaras Hindu University, India for laboratory and library facilities. The author is thankful to I.C.C.R, India for scholarship. 


\section{References}

Bormann, F.H. \& G.E. Likens. 1979. Pattern and Process in Forested Ecosystem. SpringerVerlag, New York, USA.

Bradshaw, A.D. 1987. Restoration: An acid test for ecology. In: restoration ecology: Asynthetic approach to ecological research (Eds. W.R. Jordan, M.E. Gilpin \& J.D. Aber), Cambridge University Press, Cambridge, UK. pp. 23-29.

Eno, C.F. 1960. Nitrate production in the field by incubating the soil in polyethylene bags. Soil Science Society of America Proceedings 24: 277-279.

Garwood, N.C. 1985. Earthquake caused landslides in Panama: Recovery of vegetation. National Geographic Society Research Report 21: 181-183.

Grime, J.P. 1979. Plant Strategies and Vegetation Processes. Wiley, Chichester.

Guariguata, M.R. 1990. Landslide disturbance and forest regeneration in the Upper Luquillo Mountains of Puerto Rico. Journal of Ecology 78: 814-832.

Huston, M.A. 1979. A general hypothesis of species diversity. American Naturalist 113: 81-101.

Jackson, M.L. 1958. Soil Chemical Analysis. Printice Hall, Englewood Cliffs, New Jersey.

Jenny, H., S.P. Gessel \& F.T. Bingham. 1949. Comparative study of decomposition rates of organic matter in temperate and tropical region. Soil Science 68: 419-432.

Kalembasa, S.J. \& D.S. Jenkinson. 1973. A comparative study of titremetric and gravimetric methods for the determination of organic carbon in soil. Journal of Science, Food \& Agriculture 24: 1085-1090.

Mandal, T.N. 1999. Ecological analysis of recovery of landslide damaged Sal forest ecosystem in Nepal Himalaya. Ph.D. Thesis, Center of Advanced Study in Botany, Banaras Hindu University, Varanasi, India.

Margalef, R. 1958. Information theory in ecology. General Systematics 3: 36-71.

Pastor, J., J.D. Aber, C.A. Mc Claugherty \& J.M. Melillo. 1984. Aboveground production and N and $\mathrm{P}$ cycling along a nitrogen mineralization gradient on Blackhawk Island, Wisconsin. Ecology 65: 256-268.

Pickett, S.T.A. \& P. White. 1985. The Ecology of Natural Disturbance and Patch Dynamics. Academic Press, Orlando, FL.

Pielou, E.C. 1966. The measurement of diversity in different types of biological collections. Journal of Theoretical Biology 13: 131-144.

Shannon, C.E. \& W. Weaver. 1963. The Mathematical Theory of Communication. University of Illinois Press, Urbana.

Simpson, E.H. 1949. Measurement of diversity. Nature 163: 688.

Singh, J.S. \& S.P. Singh. 1992. Forests of Himalaya. Gyanodaya Prakashan, Nainital, India.

Singh, K.P., T.N. Mandal \& S.K. Tripathi. 2001. Patterns of restoration of soil physicochemical properties in microbial biomass in different landslides sites in the Sal forest ecosystem of Nepal Himalaya. Ecological Engineering 17: 385-401

van der Maarel, E. 1993. Some remarks on disturbance and its relations to diversity and stability. Journal of Vegetation Science 4: 733-736.

Vance, E.D., P.C. Brookes \& D.S. Jenkinson. 1987. An extraction method for measuring soil microbial biomass C. Soil Biology \& Biochemistry 19: 703-707.

Wetzel, R.G. \& G.E. Likens. 1979. Limnological Analysis. W.B. Saunders Company, Philadelphia. 